\title{
Factor structure and descriptive characteristics of the Croatian version of the revised Negative Acts Questionnaire (NAQ-R) as applied in the workplace, on a sample of police officers in the Split-Dalmatia Police District
}

\author{
Željka Radošević \\ Split-Dalmatia Police District, Director's Office \\ E-mail: zradosevic@mup.hr
}

Dolores Britvić

School of Medicine, University of Split, Chair for psychological medicine

Boris Tot

Ministry of the Interior, Department for Legal Affairs and Human Resources

\section{Abstract}

Mobbing has been recognized as a psychosocial risk to the mental health of employees, but also as an organizational problem that has been the object of attention among scholars in sociological, psychological, medical, and criminologist sciences.

This study is the preparatory phase of the implementation of The Negative Acts Questionnaire-Revised (NAQ- $R$, Einarsen, Hoel and Notelaers, 2009) which tests for exposure to harassment in the workplace.

The main aim of the study was to determine whether the instruments are applicable to the sample of Croatian employees, by means of testing the factor structure and internal reliability of the said questionnaire.

The sample encompassed 209 police officers of both genders in the Split-Dalmatia Police District, and the data were acquired by means of a survey. We used descriptive statistics to show the characteristics of the sample and to analyse the findings, and we tested the factor structure by utilizing principal factor analysis, relying on the Kaiser-Guttman criterion. We tested the internal reliability of the sample with the Cronbach's Alpha coefficient.

The results suggest that there is a two-factor structure in the questionnaire, with the first factor referring to harassment aimed at the employee's personality, and the second factor referring to harassment that is aimed at the employee's work. Cronbach's Alpha coefficient shows a high level of reliability $(\alpha=0.959)$.

Keywords: negative acts in the workplace, mobbing, police officers, workplace abuse, NAQ-R

\section{Introduction}

Mobbing is considered one of the more relevant contemporary workplace problems in the area of human resource management (Nielsen et al., 2009), as it is linked to both the quality of work that is done and the employees' mental health. Leka and Cox (2008) consider mobbing a psychosocial risk in human resource management, placing it in the area of interpersonal relationships 
and finding it to be an essentially social and organizational problem. It is seen as one of the main workplace stressors, i.e. as an extreme social stressor (Hauge, Skogstad and Einarsen, 2010; Leymann, 1996; Quine, 1999; Zapf, Knorz and Kulla, 1996) which can have negative consequences for the physical and psychological health of those exposed to it, leading to the appearance of various anxious conditions (adjustment disorders, post-traumatic disorders), depressive disorders, behavioural problems, functional and psychosomatic conditions, but also potentially affecting the whole family and its functioning (Britvić, 2010). Long-term exposure to workplace stressors, i.e. professional isolation, non-existence of support, and the interpersonal relationships, may all lead to burnout syndrome as the most unfavourable consequence which is indicated by an exhaustion of motivation for work and a series of difficulties in personal relationships and in the family (Ajduković and Ajduković, 1996).

According to the European Agency for Safety and Health at Work (EU-OSHA), the psychosocial risks and stressors in work are among the greatest challenges to health and safety. Further, various forms of mobbing and workplace colleagues' inappropriate behaviours and acts form the main factors that lead to workplace stress, the problem transcending the matters of personal health, and becoming a problem of public safety and a problem of safety in the framework of human resources. According to the data compiled by EU-OSHA (2010), around $6 \%$ of employees in the EU-27 had at some point been the object of some type of violence or harassment. The Fifth European working conditions survey found that $4.1 \%$ of employees were subject to harassment or abuse in the workplace (Eurofound, 2010).

Just like other public services, the police force is subject to frequent organisational changes and management by restructuring, which results in lack of job security and conflict of roles, as well as an environment with higher levels of frustration, anxiety, stress, and tension, thereby lowering the threshold of aggression and contributing to the incidence of workplace abuse and mobbing (Baillien and De Witte, 2009; Hauge, Skogstad and Einarsen, 2009; Hoel and Cooper, 2000; Salin, 2003, 2015). Since there exists no Croatian-based instrument measuring the experience of mobbing, this pilot study and the results concerning the applicability tests ${ }^{1}$ of The Negative Acts Questionnaire-Revised (NAQ-R, Einarsen, Hoel and Notelaers, 2009) are only preliminary. This questionnaire is most often used in research on workplace harassment, as confirmed by it being referenced across various studies and in more than 40 countries (Einarsen et al., 2009; Giorgi, Arenas and Leon-Perez, 2011; Nielsen, Notelaers and Einarsen, 2011). The analyses of various samples from across the studies applying the NAQ-R instrument show that, across the board, between 3 and $4 \%$ of employees are exposed to regular and severe workplace harassment, while 9 to $15 \%$ are exposed to occasional and mild workplace harassment (Zapf, Escartin, Einarsen, Hoel and Vartia, 2011).

By examining the databases of published research (EBSCO, Science Direct, HRČAK), we have found that this questionnaire has not yet been used in Croatia, making its preliminary assessment the precondition of further research.

1 The results shown in this paper refer to the portion of the questionnaire for which the psychometric characteristics were tested as part of the doctoral dissertation on "Facing negative behaviors in the workplace, focusing on the police profession". This dissertation is where the NAQ-R questionnaire, tested in Croatia for the first time, was described. The dissertation also encompassed a discussion of questions concerning the sociodemographic characteristics, and those of the workplace and organization. 


\section{Defining and measuring mobbing}

According to Leymann (1996), the core characteristic of mobbing or psychological terror is the presence of inimical harassment and unethical acts in the form of direct or indirect negative acts that an individual is exposed to during a longer period of time. These negative acts also include social exclusion and range from subtle (e.g. denial of information, excessive and permanent supervision) to the more severe forms (e.g. threats, angry outbursts) and thus have the characteristic of a process (Einarsen, Hoel, Zapf, Cooper, 2011; Zapf and Einarsen, 2001). If systematic abuse continues for a longer time period, it may cause social, psychological, and psychosomatic problems for the victim and maladaptive behaviours in the workplace (Hoel, Sheehan, Cooper and Einarsen, 2011; Hogh, Mikkelsen and Hansen, 2011).

Mobbing can be defined as conscious or unconscious behaviour by one or more persons, directed at a victim, with the aim of removing the victim from the workplace or broad area of work by means of continued harassment. It can also be defined as conflict-laden communication among workplace colleagues or between a manager and a subordinate which aims to discriminate against or to exclude a person from the workplace by means of systematic attacks over a longer time period. These definitions clearly indicate that this is a situation of conflict which entails abuse, systematic verbal attacks, discriminatory behaviours along some of the potential bases on which discrimination is prohibited, and all with the aim of smearing someone's reputation, endangering their human dignity and integrity, and excluding them from the place of work (Bodiroga-Vukobrat, Frančišković and Pernar, 2006; Janković, Laklija and Berc, 2012). The effects on the organisation manifest as lowered dedication and efficiency of the employees, increased turnover of staff, intention to leave the workplace or take an early retirement (Bartlett and Bartlett, 2011; Hoel, Einarsen and Cooper, 2003; Lutgen-Sandvik, 2006).

According to the accepted definitions, the core characteristics of harassment in the workplace are as follows: exposure to negative behaviours (e.g. excessive control over one's work, insistent criticism, social isolation), frequency (repetition on a daily, weekly, monthly basis) and power imbalance evidenced in the victim's inability to defend herself. Workplace harassment can be direct, such as verbal abuse, accusations, public humiliation, and it can be indirect, subtle, in the form of gossip, spreading false rumours, and social exclusion (Einarsen et al., 2009).

The overview of international and Croatian literature shows that the terms mobbing and workplace harassment are synonymous and common in descriptions and research studies of the same phenomenon. The Croatian legislation relies on the term workplace harassment. In this paper, however, we use both terms and understand them to refer to the same phenomenon.

In order to measure mobbing, an operative definition was developed, based on the Leymann criterion of at least one inimical and unethical act on a weekly basis, for the duration of six months (Di Martino, Hoel and Cooper 2003; Leymann, 1990), and based on the Mikkelsen and Einarsen (2001) criterion, at least two negative acts per week over that same time period. This operative criterion may also be framed with a more strict threshold, of three or four negative behaviours a week, over at least six months, as a criterion for workplace harassment (Agervold, 2007). Alongside the exposure criterion of six months, research has also used the exposure criterion of 12 months (Yildirim, 2009; Salin, 2001). 
A key element of the definition of mobbing is that the individual exposed to the negative behaviours sees herself as a victim of these activities (Baguena, Belena, Toldos and Martinez, 2011). While some may perceive certain negative behaviours as harassment, others may be unwilling to perceive themselves as the victim and are thus avoiding characterizing their experience as harassment (Nielsen, Matthiesen and Einarsen, 2010). Various studies (Mikkelsen and Einarsen, 2001; Salin 2001) confirm the existence of this discrepancy between subjective and objective indicators of workplace harassment. Many find that admitting their status as victim also implies their personal weakness and lack of strength at dealing with stressful situations in work. It is precisely the subjective experience of workplace harassment that presents a problem for researchers and calls for a precise definition of the experience of harassment. This study utilises the approach to studying workplace that has been accepted by numerous other researchers (Einarsen et al. 2003; Leymann, 1996; Salin, 2001; Zapf and Gross, 2001), and which defines the phenomenon of workplace harassment as repeated negative activities on the part of one or more persons in a work environment, aimed at one or multiple persons who feel themselves to be the target of attacks without the possibility or with difficulty defending themselves, with these activities aimed at inflicting professional, psychosocial, psychological or physical damage, i.e. endangering the integrity of the victim.

The research on mobbing uses various measurements which results in variation in results across but also within individual countries (Nielsen et al., 2010). This variation may also be attributed to inconsistency in the use of the measurement instruments (Baguena et al., 2011; Zapf et al., 2011). Two methods of quantitative measurement are most common.

In the self-labelling method, the respondents assess their own perception of exposure to harassment over a certain period of time. Before the self-assessment, the respondents are most often also asked if they would characterize their experience as workplace harassment, given the offered definition of harassment. The self-assessment may entail dichotomous responses (yes/no) or marking their experience on a scale that refers to the frequency of harassment (from 1, meaning never, to 5, meaning daily).

The second approach is the behavioural experience method which measures the frequency of exposure to concrete negative acts on a scale from 1 (never) to 5 (daily), over a certain period of time, most often six or twelve months (Einarsen, Hoel, Zapf and Cooper, 2003; Leymann, 1996; Salin, 2001).

A significant number of studies combine both approaches, the self-assessment and behavioural experience, which allows them to achieve the best measurement operationalization in the study of mobbing (Nielsen et al., 2011), particularly with the inclusion of the definition of mobbing which is part of the self-assessment method (Zapf et al., 2011). In this way, the researchers are able to obtain the information on the nature and frequency of exposure to negative acts, i.e. the experience of workplace harassment (Nielsen et al., 2010).

Most studies that aim to assess frequency consider the period of six to twelve months prior to the point of assessment.

The behavioural experience method is most commonly used, as it is applied in instruments such as the Leymann Inventory of Psychological Terrorization — LIPT and The Negative Acts 
Željka Radošević, Dolores Britvić, Boris Tot: Factor structure and descriptive characteristics of the...

Questionnaire-Revised, NAQ-R (Einarsen and Raknes, 1997; Einarsen et al., 2009). The latter, revised questionnaire supports the measurement of workplace harassment by combining the method of behavioural experience and the self-assessment method. While the LIPT is designed as a diagnostic tool for identifying the victims of serious abuse which may also be a source of trauma, it is less appropriate in the surveys of the general workforce. The NAQ-R is an appropriate, comprehensive, and brief scale used to determine the exposure to harassment in the workplace in organisation-wide surveys (Einarsen et al., 2009).

\section{Purpose and aims of the study}

Since we are not aware of the application of The Negative Acts Questionnaire-Revised on any population of employees in Croatia, we contend that developing of the Croatian version will contribute to the research on harassment in the workplace and the comparison with the findings from other countries and organisational environments. The main purpose of this study is thus to test the factor structure and internal reliability as the preliminary test of the appropriateness of the Croatian version of the NAQ-R for future use.

With regard to the main purpose, the first aim of this article is to test the factor structure of the NAQ-R and test its internal reliability. The second aim is to demonstrate the basic descriptive indicators gathered in the application of this questionnaire and the statistical significance of the correlation between individual items and the average total score with the item of 'experience of harassment'.

\section{Method}

\section{Sample}

The participants of the study were 209 police officers in the Split-Dalmatia Police District, 161 of whom were men $(77 \%)$, and $48(23 \%)$ were women. More than half (56\%) of the respondents had been employed as police officers for more than 20 years. Most of the respondents (55.5\%) had high-school-level education, $12 \%$ had some form of higher education, and $32.5 \%$ had university-level education. With regard to their position in the organisation, $75 \%$ were in subordinate position, while $25 \%$ were in management positions. Among those in management positions, $10 \%$ were in middle and higher levels of management, while $90 \%$ were in lower levels of management.

\section{Research process}

The survey was fielded in December 2016 and January 2017, after advance notification, and during work hours. Only the police officers who were on duty at the time of the survey administrators' arrival took part. Survey participation was voluntary, and respondents' anonymity guaranteed. The questionnaires were handed out in open envelopes with both verbal and written instructions to the participants, informing them that they may at any point decide to not take part in the survey and that they should return the questionnaire, filled in or not, and without any personal information written in, into the envelope, which they should seal and leave in the provided box. This procedure ensured confidentiality and anonymity. 


\section{Instrument}

The Negative Acts Questionnaire-Revised (Einarsen et al., 2009) was created on the basis of a survey of the relevant literature and the statements by the victims of long-term harassment. The questionnaire was constructed by a group of Norwegian scientists at the University of Bergen (The Bergen Bullying Research Group).

The questionnaire provides information on the exposure to negative acts in the six months prior to the survey, and the results are grouped into three factors by means of factor analysis. The three factors refer to harassment directed at the quality of work performance (unrealistic deadlines, excessive supervision, removal of responsibilities, and similar), the individual's personality (ignoring them, spreading rumours and gossip, humiliation, and similar), and physical intimidation (pointing at the person, threats of physical violence, and similar). This factor structure was found in the original instrument. NAQ-R can also be used as a single-factor, or dual-factor measurement.

The revised questionnaire contains 22 items constructed in terms of negative and unethical behaviours, without mentioning the term 'harassment'. The respondents are given a time frame of six months (most often) within which they assess the frequency of exposure to each of the 22 negative behaviours, using a five-point scale ranging from 1 (never) to 5 (daily). The value of 1 means that the respondents has never experienced the negative behaviour, while the value of 5 means that the respondent is experiencing the negative acts / behaviour every day. There is an additional question at the end of the questionnaire which offers the definition of workplace harassment and asks the respondents to assess to which extent they are harassed, on a frequency scale ranging from 1 (never) to 5 (daily). According to the authors, the total score on the questionnaire and the additional question can be calculated as a simple linear sum, with higher values indicating a higher frequency of exposure to negative and unethical acts, i.e. a greater frequency of experienced workplace harassment.

Testing the psychometric characteristics (Einarsen et al., 2009) of the questionnaire yielded a high level of internal reliability (Cronbach's alpha $=0.90)$ with all factor saturation scores exceeding 0.70. The found factors are mutually highly correlated and confirm the satisfactory level of construct validity which was assessed by using measures of psychophysical health, work satisfaction, efficacy, dedication to the organization, and similar. The instrument was constructed in 1997 and was amended several times after that. The Negative Acts Questionnaire - Revised remedied the shortcomings of the prior Negative Acts Questionnaire and made it possible to conduct cross-cultural comparative studies (Einarsen et al., 2009). In order to conduct our survey, we gained the original authors' permission to use and translate their original English-language questionnaire. We used the back-translation method (Vallerand, 1989) which entailed having two English-teachers translate the questionnaire, exchange their translations, and create a final version of the translation into Croatian. This Croatian version was then translated into English by a third English-teacher. None of the items indicated a need to alter the translation.

The questionnaire we used was modified in the time frame aspect, as our respondents were asked about their experiences in the 12 rather than six months prior to the administration of the survey. We implemented this change with the aim of avoiding variation in measurement that stems 
Željka Radošević, Dolores Britvić, Boris Tot: Factor structure and descriptive characteristics of the...

from the changes to the police system in Croatia and from the periods of use of annual leave around the time when the survey was administered.

Alongside the NAQ-R, we also asked the respondents to fill in a portion of the survey containing sociodemographic variables, such as sex, age, their work status and organizational status.

\section{Results}

\section{Factor structure and reliability of the questionnaire}

In order to test the factor structure, the appropriateness of the correlation matrix for factor analysis was tested using the Kaiser-Meyer-Olkin test (KMO) and the Bartlett sphericity test. The $\mathrm{KMO}$ test shows the proportion of joint variance explained by the latent factors. The appropriateness of the correlation matrix for the factor structure score is considered excellent when exceeding 0.90 (Kaiser, Rice, 1974, in Fulgosi, 1988). The Bartlett test assesses whether the correlation matrix is equal to identity matrix. In order for the appropriateness of the matrix for factor analysis to be statistically significant, the p-value must be 0.05 or lower. Based on the data we collected, the correlation matrix compiled from the items in the NAQ-R satisfy the said criteria for appropriateness of factor analysis (KMO test $=0.946$; Bartlett sphericity test: approximate chi-squared $=3699.877$; $d f=231 ; p<0.001)$.

Since this is (to the best of our knowledge) the first application of the Croatian version of the NAQ-R, the factor structure of the questionnaire was tested by using the procedure of exploratory factor analysis with the principal factor method which allows for the measurement of latent factors. Further, we used the Kaiser-Guttman criterion of factor extraction that only preserves those factors that have eigenvalues equal to or higher than 1. As the tested phenomena are mutually significantly correlated, we used the diagonal oblimin rotation which allows for a more meaningful interpretation of the extracted factors.

Apart from the Kaiser-Guttman criterion which shows the tendency towards hyperfactorization, we also used the Catell scree test and the factor interpretability criterion to make the decision on the number of factors.

Table 1 Extracted eigenvalues in the NAQ-R based on the principal factors model and the use of the Kaiser-Guttman criterion

\begin{tabular}{|c|c|c|c|}
\hline \multirow{2}{*}{ Factor } & \multicolumn{3}{|c|}{ Principal factors analysis } \\
\cline { 2 - 4 } & Eigenvalues & Proportion of variance & Cumulative proportion of variance \\
\hline 1 & 11.910 & 54.134 & 54.134 \\
\hline 2 & 1.107 & 5.032 & 59.166 \\
\hline 3 & 0.753 & 3.423 & 62.589 \\
\hline
\end{tabular}

As can be seen in Table 1, factor analysis based on the principal factors model and following the Kaiser-Guttman criterion has extracted two significant factors that jointly explain $59.166 \%$ of joint variance. Even though there is a great difference in the proportion of explained variance of the first factor, which explains $54.134 \%$ of joint variance, compared to the others, we also allow for the presence of the second factor which explains $5.032 \%$ of joint variance. This speaks to the presence of a two-factor structure of the tested questionnaire, which is also confirmed by visual inspection of the Cattell scree test (Image 1), which was our second criterion when deciding on the number of factors. 


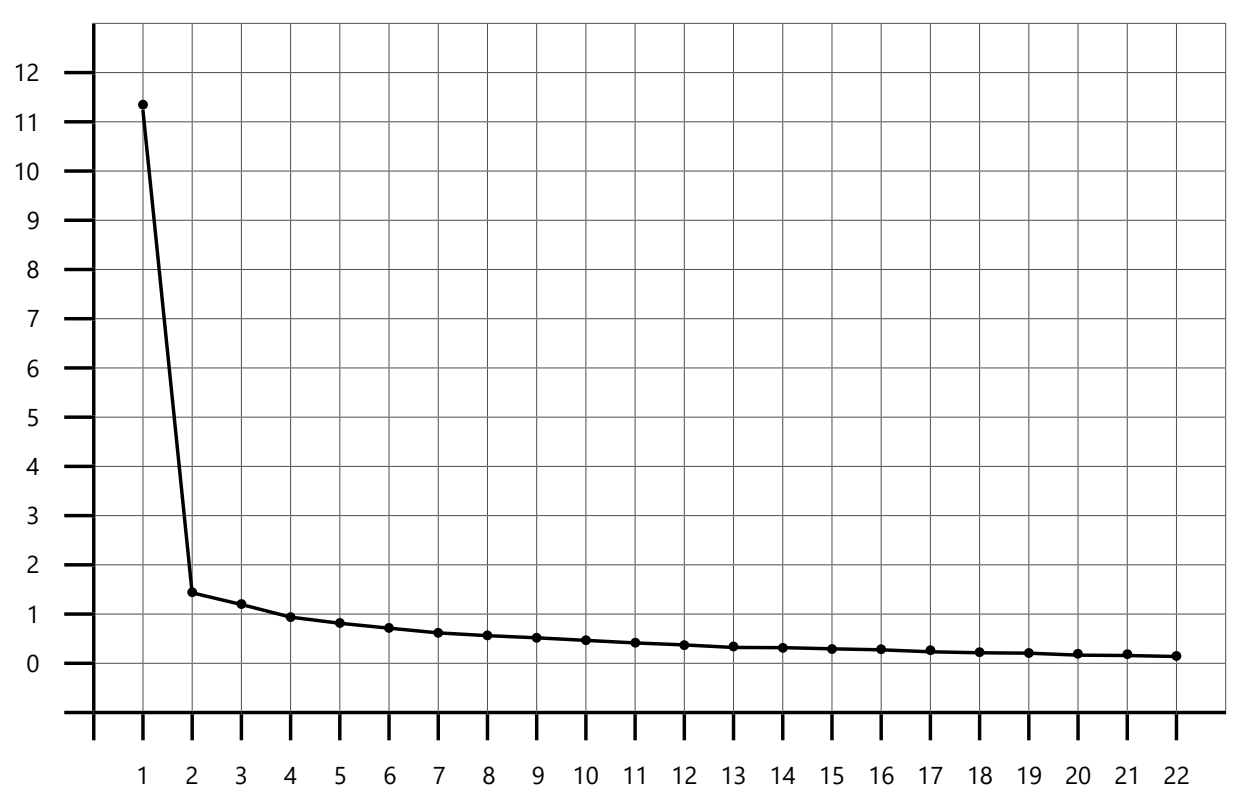

\section{Image 1 NAQ-R number of factors based on the Cattell scree test. $N$ of factors on the $x$-axis; eigenvalues on the $y$-axis}

By examining the scree plot in Image 1, we see a significant drop in the eigenvalues (characteristic root values) after the first factor, which indicates that the theoretically relevant amount of variation was exhausted on the first factor. We also see a much smaller, but also significant drop after the second factor. This solution suggests that there is a two-factor structure in the Croatian questionnaire. By taking into account the results of previous research (Einarsen et al., 2009; Charilaos et al., 2015), which allow for the NAQ-R to be used as a single-factor, a three-factor (harassment directed at the employee's personality, harassment directed at their work, and physical intimidation) or a two-factor measurement instrument (harassment directed at the employee's personality and harassment directed at their work), the remainder of this article, in line with the research on isolated significant factors, demonstrates the rotated factor solution with two meaningful factors that satisfy the interpretability criterion (harassment directed at the employee's personality and harassment directed at their work). We sorted the item in the pattern matrix, structure matrix, and the communalities matrix (Table 2) according to saturation level, leaving out any saturations under 0.30 both for the purpose of better visibility and because we wanted to make it easier to identify the items that belong on the same factor. The conducted analysis with two given factors $\left(\kappa_{1}=11.879\right.$, $53.995 \% ; K_{2}=1.079,4.907 \%$ ) explains a total of $58.902 \%$ of joint variance. Correlation between the two factors is positive and statistically significant $\left(r_{\mathrm{F} 1, \mathrm{~F} 2}=0.664, \mathrm{p}<0.001\right)$. 
Željka Radošević, Dolores Britvić, Boris Tot: Factor structure and descriptive characteristics of the...

Table 2 NAQ-R pattern matrix (P), structure matrix (S) and communalities (h2) after diagonal oblimin rotation

\begin{tabular}{|c|c|c|c|c|c|}
\hline Items & P1 & $\mathbf{P 2}$ & S1 & S2 & $\mathbf{h}^{2}$ \\
\hline $\begin{array}{l}\text { NAQ-R 9. Intimidating behaviour such as finger-pointing, invasion of personal space, } \\
\text { shoving, blocking/barring the way }\end{array}$ & 0.910 & & 0.840 & 0.499 & 0.711 \\
\hline NAQ-R 20. Being the subject of excessive teasing and sarcasm & 0.875 & & 0.859 & 0.557 & 0.738 \\
\hline NAQ-R 22. Threats of violence or physical abuse or actual abuse & 0.820 & & 0.663 & 0.307 & 0.471 \\
\hline NAQ-R 17. Having allegations and accusations made against you. & 0.797 & & 0.804 & 0.540 & 0.646 \\
\hline NAQ-R 8. Being shouted at or being the target of spontaneous anger (or rage) & 0.794 & & 0.811 & 0.553 & 0.658 \\
\hline NAQ-R 15. Jokes are made at your expense. & 0.776 & & 0.800 & 0.551 & 0.640 \\
\hline NAQ-R 12. Being ignored or facing a hostile reaction when you approach & 0.733 & & 0.817 & 0.614 & 0.677 \\
\hline $\begin{array}{l}\text { NAQ-R 10. Hints or signals from others that you should stop doing your job, seek } \\
\text { another job, or quit your job }\end{array}$ & 0.731 & & 0.737 & 0.494 & 0.543 \\
\hline $\begin{array}{l}\text { NAQ-R } 7 \text {. Having insulting or offensive remarks made about your person (i.e. habits and } \\
\text { background), your attitudes or your private life }\end{array}$ & 0.704 & & 0.769 & 0.566 & 0.597 \\
\hline NAQ-R 11. Your mistake(s) are constantly brought up or actively sought. & 0.660 & & 0.775 & 0.611 & 0.617 \\
\hline NAQ-R 13. Your work is persistently criticized & 0.638 & & 0.801 & 0.669 & 0.675 \\
\hline NAQ-R 18. Excessive monitoring or control of your work & 0.557 & & 0.707 & 0.596 & 0.528 \\
\hline NAQ-R 2. Being humiliated or ridiculed in connection with your work & 0.535 & 0.338 & 0.759 & 0.693 & 0.640 \\
\hline NAQ-R 5. Spreading of gossip and rumours about you. & 0.466 & & 0.619 & 0.539 & 0.412 \\
\hline NAQ-R 21. Being exposed to an unmanageable workload & 0.392 & & 0.510 & 0.438 & 0.278 \\
\hline $\begin{array}{l}\text { NAQ-R 19. Pressure not to claim something which by right you are entitled to (e.g. } \\
\text { overtime pay, sick leave, holiday entitlement, travel expenses) }\end{array}$ & 0.371 & 0.328 & 0.589 & 0.574 & 0.407 \\
\hline NAQ-R 1. Someone withholding information which affects your work. & & 0.835 & 0.504 & 0.801 & 0.644 \\
\hline $\begin{array}{l}\text { NAQ-R 4. Having key areas of responsibility removed or replaced with more trivial or } \\
\text { unpleasant tasks }\end{array}$ & & 0.799 & 0.583 & 0.834 & 0.697 \\
\hline NAQ-R 3. You are given work below your level of competence. & & 0.657 & 0.513 & 0.708 & 0.505 \\
\hline NAQ-R 14. Your potential is ignored and your opinion neglected. & 0.325 & 0.580 & 0.711 & 0.797 & 0.694 \\
\hline NAQ-R 6. You are ignored, excluded, and isolated from current goings-on. & 0.383 & 0.497 & 0.713 & 0.751 & 0.646 \\
\hline NAQ-R 16. Being given tasks with unreasonable or impossible targets or deadlines & 0.357 & 0.443 & 0.650 & 0.679 & 0.533 \\
\hline
\end{tabular}

Our interpretation of the factors is based on the factor structure matrix after factor rotation and identification of those variables that are highly saturated on a particular factor. Factor saturation indicates the relative importance of each variable in defining the factor, with higher saturation meaning that the variable is better at describing the factor. Even though there are no clearly defined and broadly accepted criteria for determining statistical significance of factor saturation, we have decided on a sample-size-based criterion for identifying statistically significant saturation. According to Hair et al. (Hair, Black, Babin and Anderson, 2010), factor saturation between +/- 0.30 to +/-0.40 fulfil minimal requirements for factor interpretation, those around $+/-0.50$ are considered quite significant, and those of $+/-0.70$ or higher are considered indicative of a well-defined factor structure. Our sample size is 209, which means that the sample-size criterion for identifying statistically significant saturation at $95 \%$ level $(p<0.05)$ requires factor saturation of at least $+/-0.40$. As can be seen from Table 2, the factor saturation levels match the statistical significance criterion, as they range from 0.44 to 0.91 . We used a higher level of saturation to determine the variables belonging to the second factor (higher than $+/-0.65$ ), which matches the criteria for statistical significance based on the size of the sample and needs of interpretation.

Examining the factor saturation results and the correlation variables with the latent factors (Table 2), we find that the first factor, which describes the largest portion of the joint variance, includes 16 items, with the highest levels of saturation on items NAQ-R 9 ('Intimidating behaviour 
such as finger-pointing, invasion of personal space, shoving, blocking / barring the way'), NAQ-R 20 ('Being the subject of excessive teasing and sarcasm'), NAQ-R 22 ('Threats of violence or physical abuse or actual abuse'), NAQ-R 17 ('Having allegations and accusations made against you'), NAQ-R 8 ('Being shouted at or being the target of spontaneous anger (or rage)'), NAQ-R 15 ('Jokes are made at your expense'), These items describe acts that stem from interpersonal relationships and can be summarized a harassment aimed at the employee's personality.

As in the other studies that allow for a two-factor structure of the NAQ-R (Charilaos et al., 2015), the NAQ-R items 8, 9, and 22, describing physical intimidation (Einarsen, Hoel, and Notelaers, 2009) are projected on the first factor and are relevant in defining the harassment aimed at the employee's personality. The second factor describes six items and is most highly saturated with items NAQ-R 1 ('Someone withholding information which affects your work'), NAQ-R 4 ('Having key areas of responsibility removed or replaced with more trivial or unpleasant tasks'), NAQ-R 3 ('You are given work below your level of competence'), NAQ-R 14 ('Your potential is ignored and your opinion neglected'), NAQ-R 6 ('You are ignored, excluded, and isolated from current goings-on'), and NAQ-R 16 ('Being given tasks with unreasonable or impossible targets or deadlines'). These items concern the situations in which an employee is prevented from activities that constitute her job. Thus, the second factor may be thought of as exposure to harassment aimed at the employee's work (unrealistic deadlines, excessive workload, opinions and attitudes being ignored, excessive supervision, removal of responsibilities, and similar).

Internal reliability of the NAQ-R was measured using Cronbach's alpha coefficient and indicates a high level of reliability (Cronbach's $\alpha=0.959$ ). Mean correlation between the items in the instrument is also high and at a satisfactory level $(r=0.531$; $\operatorname{Min}=0.233$, $\operatorname{Max}=0.769)$.

The first factor (F1 - harassment aimed at the employee's personality) and the second factor (F2 - harassment aimed at the employee's work) have also been descriptively analysed for our sample ( $N=209)$, and Table 3 shows their mean values $(M)$, dispersal (SD), range (Min - Max), internal reliability (Cronbach's alpha), mean correlation between factor items $\left(r_{\mathrm{F}}\right)$, and correlation with the item of harassment experience.

By considering the descriptive statistics we can conclude that the experience of harassment as described on the first factor ( $F 1$ - harassment aimed at the employee's personality, $M=1.68$, $S D=0.70$ ) and on the second factor ( $F 2$ - harassment aimed at the employee's work; $M=2.10$, $\mathrm{SD}=0.89$ ) is only rare and found at a frequency of several times a year. This matches the result for the analysis of all items in the questionnaire $(M=1.79 ; S D=0.72)$. Internal reliability and mean correlation between the items on the first factor (Cronbach's $\alpha$ F1 $=0.949 ; r F 1=0.553$ ) and on the second factor (Cronbach $\alpha$ F2 $=0,896$; rF2 $=0,595$ ) have been tested using Student's t-test for independent samples. The results show, with statistical significance, that the respondents' answers on the tested factors differ $(t=11.11 ; d f=208, p<0.001)$. Furthermore, this indicates that, though very rare, harassment of the second factor type (harassment aimed at the employee's work) is more present.

We have also found high and statistically significant correlations $(p<0.001)$ between the item describing the 'frequency of exposure to harassment' and both the first $(r=0.625)$ and the second factor $(r=0.538)$. 
Željka Radošević, Dolores Britvić, Boris Tot: Factor structure and descriptive characteristics of the...

Table 3 Mean values (M), dispersal (SD), range (Min - Max), correlations ( $\left.r_{p}\right)$ on the first and second factor of the NAQ-R $(N=209)$

\begin{tabular}{|l|c|c|c|c|c|c|c|}
\hline \multicolumn{1}{|c|}{ Factors } & M & SD & Min & Max & Cronbach's $\boldsymbol{\alpha}$ & rF & $\mathbf{r}$ (experience of harassment) \\
\hline $\begin{array}{l}\text { F1 harassment aimed at the employee's } \\
\text { personality }\end{array}$ & 1.68 & 0.70 & 1 & 4.81 & 0.949 & 0.553 & $0.625^{* *}$ \\
\hline F2 harassment aimed at the employee's work & 2.10 & 0.89 & 1 & 5 & 0.896 & 0.595 & $0.538^{* *}$ \\
\hline
\end{tabular}

\section{Prevalence of negative acts in the workplace}

The descriptive analysis demonstrates that there is a presence of the measured phenomena in the sample, which was the second specific aim of this study. We are presenting the descriptive values on the items for the applied NAQ-R and the statistical significance of the correlation between individual items and the total mean score with the item 'experience of being harassed'.

Table 4 shows the mean values (M), dispersal (SD), and range of results on individual items and the total score on the NAQ-R and the additional item that tests the frequency of exposure to harassment (Min-Max). We are also showing the correlations between individual items and the total score on the NAQ-R with the item that tests the experience / frequency of being harassed (Pearson's $r$ ). The results of the descriptive analysis show that the mean values of items are found from $M=1.22$ ( $S D=0.51$ ) for item NAQ-R 22 (Threats of violence or physical abuse or actual abuse) to $M=2.35$ ( $S D=1.22$ ) for item NAQ-R 3 (You are given work below your level of competence). The analysis of mean values on the whole scale (total score) shows that only seven respondents (3.3\%) score $M=3.5$ and higher which matches the assessment of exposure to negative acts on a daily and weekly level. Since the questionnaire concerns the frequency of exposure to negative acts, the results suggest, at a descriptive level, that the tested acts occur rarely or never for the examined sample. It is important to point out that there is a near-negligible presence of threats of violence or actual violence (item NAQ-R 22, $M=1.12$, SD $=0.51$ ). A total of 193 respondents $(92.3 \%)$ gave the answer of 1 (never) to the question on the experience of threats of violence or physical abuse, or actual experienced physical violence. Among these, there were 149 men (92.5 $\%)$ and 44 women (91.7\%). 
Table 4 Mean values (M), dispersal (SD), range (Min - Max) and correlations (Person's $r$ ) calculated from our application of the NAQ- $R(N=209)$

\begin{tabular}{|c|c|c|c|c|c|}
\hline NAQ-R & M & SD & Min & Max & r (experience of harassment) \\
\hline 1. Someone withholding information which affects your work. & 2.33 & 1.44 & 1 & 5 & $0.358^{\star *}$ \\
\hline 2. Being humiliated or ridiculed in connection with your work & 1.79 & 0.99 & 1 & 5 & $0.475^{\star *}$ \\
\hline 3. You are given work below your level of competence. & 2.35 & 1.22 & 1 & 5 & $0.409^{\star \star}$ \\
\hline $\begin{array}{l}\text { 4. Having key areas of responsibility removed or replaced with } \\
\text { more trivial or unpleasant tasks }\end{array}$ & 2.19 & 1.21 & 1 & 5 & $0.470^{* *}$ \\
\hline 5. Spreading of gossip and rumours about you. & 2.18 & 1.07 & 1 & 5 & $0.396^{\star \star}$ \\
\hline $\begin{array}{l}\text { 6. You are ignored, excluded, and isolated from current } \\
\text { goings-on. }\end{array}$ & 1.97 & 1.04 & 1 & 5 & $0.441^{* *}$ \\
\hline $\begin{array}{l}\text { 7. Having insulting or offensive remarks made about your person } \\
\text { (i.e. habits and background), your attitudes or your private life }\end{array}$ & 1.98 & 1.06 & 1 & 5 & $0.468^{* *}$ \\
\hline $\begin{array}{l}\text { 8. Being shouted at or being the target of spontaneous anger } \\
\text { (or rage) }\end{array}$ & 1.76 & 0.96 & 1 & 5 & $0.539^{\star *}$ \\
\hline $\begin{array}{l}\text { 9. Intimidating behaviour such as finger-pointing, invasion of } \\
\text { personal space, shoving, blocking/barring the way }\end{array}$ & 1.33 & 0.74 & 1 & 5 & $0.516^{\star \star}$ \\
\hline $\begin{array}{l}\text { 10. Hints or signals from others that you should stop doing your } \\
\text { job, seek another job, or quit your job }\end{array}$ & 1.36 & 0.84 & 1 & 5 & $0.533^{* *}$ \\
\hline 11. Your mistake(s) are constantly brought up or actively sought. & 1.74 & 0.96 & 1 & 5 & $0.577^{\star \star}$ \\
\hline 12. Being ignored or facing a hostile reaction when you approach & 1.57 & 0.85 & 1 & 5 & $0.474^{\star \star}$ \\
\hline 13. Your work is persistently criticized & 1.79 & 0.90 & 1 & 5 & $0.555^{\star \star}$ \\
\hline 14. Your potential is ignored and your opinion neglected. & 2.07 & 1.02 & 1 & 5 & $0.506^{\star \star}$ \\
\hline 15. Jokes are made at your expense. & 1.64 & 0.93 & 1 & 5 & $0.498^{\star *}$ \\
\hline $\begin{array}{l}\text { 16. Being given tasks with unreasonable or impossible targets or } \\
\text { deadlines }\end{array}$ & 1.67 & 0.95 & 1 & 5 & $0.460^{\star \star}$ \\
\hline 17. Having allegations and accusations made against you. & 1.75 & 0.96 & 1 & 5 & $0.445^{\star \star}$ \\
\hline 18. Excessive monitoring or control of your work & 1.94 & 1.03 & 1 & 5 & $0.445^{\star *}$ \\
\hline $\begin{array}{l}\text { 19. Pressure not to claim something which by right you are } \\
\text { entitled to (e.g. overtime pay, sick leave, holiday entitlement, } \\
\text { travel expenses) }\end{array}$ & 1.68 & 1.05 & 1 & 5 & $0.401^{\star \star}$ \\
\hline 20. Being the subject of excessive teasing and sarcasm & 1.45 & 0.81 & 1 & 5 & $0.542^{\star *}$ \\
\hline 21. Being exposed to an unmanageable workload & 1.78 & 0.97 & 1 & 5 & $0.315^{\star \star}$ \\
\hline 22. Threats of violence or physical abuse or actual abuse & 1.12 & 0.51 & 1 & 5 & $0.504^{\star \star}$ \\
\hline Total (all items) & 1.79 & 0.72 & 1 & 4.77 & $0.626 * *$ \\
\hline Experience of harassment & 1.30 & 0.64 & 1 & 5 & 1.000 \\
\hline
\end{tabular}

** $\mathrm{p}<0.001$

The results were similar for the item that tested the frequency of the experience of being harassed, which for this sample had the mean value of $M=1.30(S D=0.64)$. This statistic suggests that most of the respondents chose answers that deny such experiences ( $N=159,76.1 \%)$, i.e. that its incidence is quite rare $(\mathrm{N}=42,20.1 \%)$. Taking sex into account, the experience of being harassed was completely denied by 120 male respondents (74.5\%) while the response of 'very rarely' was given by 34 (21.1\%); among the women, 39 gave the answer of 'never' ( $81.3 \%$ ) and 8 gave the answer of 'very rarely' (16.7\%). This suggests that the daily, monthly, or weekly experience of harassment is quite rare, and indicated by 7 male respondents ( $4.3 \%$ ) and one female respondent ( $2.1 \%)$. Of course, the consequences and suffering caused by harassment for both the physical and mental health of those experiencing it mean that even these small figures are too high and unacceptable.

Further, we were interested in determining the level of correlation between the item 'frequency of being harassed' and the items in the NAQ-R. As can be seen in Table 4, the correlations 
Željka Radošević, Dolores Britvić, Boris Tot: Factor structure and descriptive characteristics of the...

are positive and statistically significant $(p<0.001)$ and range from $r=0.315$ to $r=0.588$. This also applies to the correlation with the mean of all scores for each individual $(r=0.626)$.

\section{Discussion}

This study has tested the factor structure and internal reliability of the Croatian version of the NAQ-R. We have kept the original structure of the instrument with regard to the number and content of the items. The time period for which the respondents were asked to assess their exposure to negative acts and self-assess the frequency of harassment was modified by setting it to 12 months, as opposed to six in the original instrument.

The factor analysis extracted two significant factors that jointly explain $59.166 \%$ of joint variance, which is in line with other studies that found a two-factor structure to the NAQ-R (Charilaos et al., 2015). Correlation between the factors is 0.664 . Based on the sample-size criterion for identifying statistically significant saturation with $95 \%$ probability $(p<0.05)$, we found that saturations on both factors are statistically significant at 0.05 level (saturation over 0.40 ). The two factors are meaningfully interpretable according to the original idea of the questionnaire's authors (Einarsen et al., 2009). The first factor contains 16 items that substantively refer to the description of harassment aimed at the employee's personality, while the second factor contains six items that can be termed exposure to harassment aimed at the employee's work. As expected and in line with the findings concerning the original questionnaire, we have found a high level of internal reliability of the whole questionnaire (Cronbach's alpha $=0.959)$ and the entire questionnaire (Cronbach's $\alpha_{\mathrm{F} 1}$ $=0.949 ;$ Cronbach's $\alpha$ F2 $=0.896$ ).

On the descriptive statistics side, we found that the experience of harassment described by the first factor (F1 - harassment aimed at the employee's personality) and on the second factor (F2 - harassment aimed at the employee's work) is rare in the examined sample (occurs several times a year). Further, there is a small but statistically significant difference between the two examined factors $(p<0.001)$ which suggest that the harassment aimed at the employee's work is more frequent in our sample. These results were also found in other studies that confirmed the appropriateness of the two-factor structure of the questionnaire (Jimenez, Munoz, Gamarra, Herrer, 2007; Silva, Aquino, Pinto, 2017).

In relation to the proposed models of the factor structure (one, two, or three factors; Einarsen et al., 2009), the tests of the NAQ-R factor structure have found a presence of the single-factor structure (Tsuno, Kawakami, Inoue and Abe, 2010; Vukelić, Čizmić, Petrović, Tenjović and Giorgi, 2015), or of a three-factor structure (Chirila and Ticu, 2014), which may be related to the possible effect of cultural differences. Taking these proposed models and the found factor structures into account, as well as considering our finding of a two-factor structure, we surmise that there is a need for further development of the instrument on a larger sample and on different populations of employees.

In our sample of police officers, the instrument has displayed a high coefficient of internal reliability (Cronbach's alpha $=0.959)$. This coefficient is similar or greater than the reliability 
measures in other studies, which makes comparison possible (Charilaos et al., 2015; Tsuno et al., 2010; Vukelić et al., 2015; Nielsen et al., 2009).

Additionally, we have also found a high and statistically significant correlation between the total result on the items of negative acts and the self-assessment of harassment $(r=0.626, p<$ 0.001 ), which is in line with previous research that finds correlation ranging from $r=0.54$ to $r=$ 0.64, at $p<0.001$ level (Charilaos et al., 2015; Einarsen et al., 2009; Tsuno et al., 2010).

By using the self-assessment method in our study, we have found that daily, monthly or weekly incidence of harassment was reported by one female respondent $(2.1 \%)$ and seven male respondents ( $4.3 \%$ ), which is in line with the expectations from previous applications of the NAQ-R. In the study by Salin (2001) among professionals in business management, with a sample of 377 , $1.6 \%$ of respondents self-reported as victims of harassment in the 12 months prior to the study. The same study found that $24.1 \%$ respondents were exposed to at least one negative act on a weekly basis for a period of 12 months.

The study by Nielsen et al. (2009) with the time frame of six months (Leymann criterion of exposure to negative acts on a daily basis or two to three times a week) found that $6.2 \%$ of respondents experienced harassment, while the application of the Mikkelsen and Einarsen criterion of at least two negative acts a day or two to three times a week found that $14.3 \%$ of respondents were experiencing harassment. The self-assessment method yielded the result of $4.6 \%$ of respondents stating that they are harassed. With regard to these results, the method of self-assessment yields a relatively lower prevalence rate compared to the behavioural experience method.

\section{Advantages and limitations of the study}

This is the first study in the Republic of Croatia that tests the appropriateness of the use of the NAQ-R measurement instrument, which has been widely used in international studies. This study is therefore an important contribution to the development of the instrument which enable the identification and understanding of negative acts and harassment in the workplace, as there is no context-specific instrument developed for studying this phenomenon in Croatia. By using this instrument, we are making possible the comparison of Croatian data with those found in international studies. The frequency of harassment in the workplace varies from country to country, due to national and cultural differences, but differences may also be expected to stem from differences between various types of organizations, which have their own contexts and organizational cultures.

These results need to be taken with caution, as they were based on a survey of a relatively small sample of a single profession in Croatia, making it important that the instrument is tested on a larger sample and other groups of employees. In order to facilitate the comparison between our results and other data our priority was to apply a uniform methodology which will allow for further development of this instrument and may serve as standard for acquisition of data on workplace harassment.

A further limitation of this study is the small number of female respondents, but it does not preclude the comparison of the factor structure. 
Željka Radošević, Dolores Britvić, Boris Tot: Factor structure and descriptive characteristics of the...

The research instrument contains self-assessment methods only, which incurs the risk of motivation and socially desirable responses, particularly in the portion which refers to the perception of victimization.

\section{Conclusion}

As the negative acts and harassment in the workplace are a significant source of stress in the workplace, but also a psychosocial risk to the mental health of the employees, it is imperative that a methodology be developed which would contribute to detection and recognition of these phenomena and take us a step closer to effective prevention.

This study has been useful as a test and further verification and application of the NAQ-R instrument in measuring workplace harassment and related factors that affect both the health of the individual and the organization as a whole. It is precisely the development of the Croatian version of this questionnaire that represents a significant contribution to recognizing and uncovering the negative acts and harassment in the workplace, which further enables the possibility of the instrument's application in various work environments and organizations, with the aim of early detection of environments that see a higher prevalence of harassment. This opens up the path towards development of more effective models of prevention of mobbing in our post-war society.

The instrument we used to measure the frequency of harassment in the workplace has a high level of internal reliability. Further, based on the results of the factor analysis, the Croatian version of the NAQ-R has a two-factor structure, with the first factor referring to harassment directed at the employee's personality, while the other refers to harassment aimed at the employee's work.

The application and development of the applied instrument in the studies of workplace harassment will contribute to better understanding of the phenomenon and development of strategies of prevention.

\section{References}

Agervold, M. (2007). Bullying at work: A discussion of definitions and prevalence, based on an Empirical Study. Scandinavian Journal of Psychology, 48, 161-172. https://doi.org/10.1111/ j. 1467-9450.2007.00585.x

Ajduković, M., Ajduković, D. (1996). Pomoć i samopomoć u skrbi za mentalno zdravlje pomagača [Help and self-help in care for the assistants' mental health]. Zagreb: Društvo za psihološku pomoć.

Baillien, E., De Witte, H. (2009). Why is organizational change related to workplace bullying? Role conflict and job insecurity as mediators. Economic and Industrial Democracy, 30 (3), 348-371. doi:10.1177/0143831X09336557

Baguena, M.J., Belena, M.A., Toldos, M.D., Martinez, D. (2011). Psychological harassment in the workplace: Methods of evaluation and prevalence. The Open Criminology Journal, 4(Suppl 2-M7), 102-108. Accessed at $h t t p s: / / p d f s . s e m a n t i c s c h o l a r . o r g / 9394 / d 7 c 9 c 4 a-$ 51d2e4746673f6097dd6314dbb857.pdf. (2/12/2016)

Bartlett, J. E., Bartlett M. E. (2011). Workplace bullying: An integrative literature review. Advances in Developing Human Resources, 13 (1), 69-84. doi: 10.1177/1523422311410651 
Britvić, D. (2010). Obitelj i stress [Family and stress]. Medicina Fluminensis, 46(3), 267-272.

Bodiroga-Vukobrat, N., Frančišković, T., Pernar, M. (2006). Mobbing. Rijeka: Društvo psihologa Primorsko-goranske županije.

Charilaos, K., Michael, G., Chryssa, B.T., Panagiota, D., George, C.P., Christina, D. (2015). Validation of the Negative Acts Questionnaire (NAQ) in a Sample of Greek Teachers. Psychology, 06(1), pp.63-74. http://dx.doi.org/10.4236/psych.2015.61007

Chirilă, T., Ticu, C. (2014). Verifying the psychometric properties of two instruments measuring workplace bullying among Romanian employees. Annals of Alexandru loan Cuza University, Psychology Series, 3(1): 91-109. Accessed at $h$ ttps://www.ceeol.com/search/ article-detail?id=82660. $(5 / 12 / 2016)$

Di Martino, V., Hoel, H., Cooper, C.L. (2003). Preventing violence and harassment in the workplace. European Foundation for the Improvement of Living and Working Conditions Accessed at $h t t p s: / / w w w . e u r o f o u n d . e u r o p a . e u / s i t e s / d e f a u l t / f i l e s / e f f f i l e s / p u b d o c s / 2002 / 109 / e n / 1 /$ ef02109en.pdf. (2/11/2016)

Einarsen, S., Hoel, H., Notelaers, G. (2009). Measuring exposure to bullying and harassment at work: Validity, factor structure and psychometric properties of the Negative Acts Questionnaire - Revised. Work and Stress, 23(1), 24-44.

Einarsen, S., Hoel, H., Zapf, D., Cooper, C.L. (2003). The concept of bullying at work: The European tradition. In: Einarsen, S., Hoel, H., Zapf, D., Cooper, C.L. (Eds.), Bullying and emotional abuse in the workplace. International perspectives in research and practice, Taylor and Francis, London, 3-30. Accessed at https://www.taylorfrancis.com/ books/e/9780203164662. (8/9/2016)

Einarsen, S., Hoel, H., Zapf, D., Cooper, C.L. (2011). The concept of bullying and harassment at work: The European tradition. In: Einarsen, S., Hoel, H., Zapf, D., Cooper, C.L. (Eds.), Bullying and harassment in the workplace. Developments in theory, research, and practice (2nd ed.), CRC Press, pp. 3-40. Accessed at https://www.researchgate.net/file.PostFileLoader. html?id...assetKey... (8/11/2016)

Einarsen, S., Raknes, B.I. (1997). Harassment in the workplace and the victimization of men. Violence and Victims, 12(3), 247-263.

Eurofound-European Foundation for the Improvement of Living and Working Conditions, European Working Conditions Survey (EWCS) - mapping the results, 2010. Accessed at $h t t p s: / /$ www.eurofound.europa.eu (15/11/2016)

Fulgosi A. (1988). Faktorska analiza [Factor Analysis]. Zagreb: Školska knjiga.

Giorgi, G., Arenas, A., Leon-Perez J.M. (2011). An Operative Measure of Workplace Bullying: The Negative Acts Questionnaire Across Italian Companies. Industrial Health, 49, 686-695.

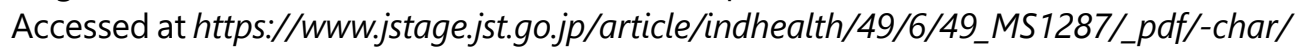
en. $(6 / 11 / 2016)$

Hair, J., Black, W., Babin, B., Anderson, R. (2010). Multivariate Data Analysis - A Global Perspective. New Jersey: Pearsib.

Hauge, L. J., Skogstad, A., Einarsen, S. (2009). Individual and situational predictors of workplace bullying: Why do perpetrators engage in the bullying of others? Work \& Stress, 23, 349-358. https://doi.org/10.1080/02678370903395568 
Željka Radošević, Dolores Britvić, Boris Tot: Factor structure and descriptive characteristics of the...

Hauge, L.J., Skogstad, A., Einarsen, S. (2010). The relative impact of workplace bullying as a social stressor at work. Scandinavian Journal of Psychology, 51(5), 426-433. doi: 10.1111/j.1467-9450.2010.00813.x

Hoel, H., Cooper, C. (2000). Destructive conflict and bullying at work. Extracts of study report compiled for Launch of the Civil Service Race Equality Network. Manchester School of Management University of Manchester Institute Science and Technology (UMIST). Accessed at $h t t p s: / /$ scholar.google.hr/scholar?q $=$ Hoel $_{1}+H_{.},+$Cooper $_{1}+C_{.}+(2000) .+$ Destructive +conflict + and + bullying + at + work. $\& h l=h r \& a s_{-} s d t=0 \& a s_{-} v i s=1 \& o i=$ scholart . $(2 / 12 / 2016)$

Hoel, H., Einarsen, S., Cooper, C.L. (2003). Organizational Effects of Bullying. In: Einarsen, S., Hoel, H., Zapf, D., Cooper C.L. (Eds.). Bullying and Emotional Abuse in the Workplace. London, UK: Taylor and Francis, 145-161.

Hoel, H., Sheehan, M. J., Cooper, C. L., Einarsen, S. (2011). Organisational effects of workplace bullying. In: Einarsen S., Hoel H., Zapf D., Cooper C.L., (Eds.), Bullying and harassment in the workplace: Developments in Theory, Research, and Practice (2nd ed.; pp. 129-148). Boca Raton, FL: CRC Press.

Hogh, A., Mikkelsen, E. G., Hansen, A. M. (2011). Individual consequences of workplace bullying/ mobbing. In: Einarsen S., Hoel H., Zapf D., Cooper C.L., (Eds.). Bullying and Harassment in the workplace: Developments in Theory, Research, and Practice. CRC Press. Taylor and Francis; pp 107-128.

Yildirim, D. (2009). Bullying among nurses and its effects. International Nursing Review, 56(4), 504-511. doi/pdf/10.1111/j.1466-7657.2009.00745.x

Janković, J., Laklija, M., Berc, G. (2012). Percepcija sukoba radne i obiteljske uloge u kontekstu nekih obilježja obitelji i posla [Percepction of the conflict between the work and family role in the context of some characteristics of the family and the workplace]. Kriminologija i socijalna integracija, 20(1), 1-132. Accessed at https://hrcak.srce.hr/file/126642. $(8 / 10 / 2016)$

Jiménez, B.M., Muñoz, A.R., Gamarra, M.M., Herrer, M.G. (2007). Assessing workplace bullying: Spanish validation of a reduced version of the Negative Acts Questionnaire. Spanish Journal of Psychology, 10(2):449-457. doi: 10.1017/S1138741600006715

Leka, S., Cox, T. (2008). The European Framework for Psychosocial Risk Management: PRIMA-EF. Nottingham (UK): I-WHO publications. Accessed at http://www.prima-ef.org/uploads/1/1/0/2/11022736/prima-ef_ebook.pdf. (15/11/2016)

Leymann, H. (1990). Mobbing and psychological terror at workplaces. Violence and Victims, 5 , 119-126. Accessed at http://www.mobbingportal.com/LeymannV\&V1990(3).pdf. (21/10/2016)

Leymann, H. (1996). The content and development of mobbing at work. European Journal of Work and Organisational Psychology, 5, 165-184. doi.org/10.1080/13594329608414853

Lutgen-Sandvik, P. (2006). Take this job and ...: Quitting and other forms of resistance to workplace bullying. Communication Monographs, 73, 406-433. doi: 10.1080/03637750601024156

Mikkelsen, E.G., Einarsen, S. (2001). Bullying in Danish work life: Prevalence and health correlates. European Journal of Work and Organizational Psychology, 10(4), 393-414. doi. org/10.1080/13594320143000816 
Nielsen, M.B., Skogstad, A., Matthiesen, S.B., Glasø, L., Aasland, M.S., Notelaers, G., Einarsen, S. (2009). Prevalence of workplace bullying in Norway: comparisons across time and estimation methods. European Journal of Work and Organizational Psychology, 18, 81-101. doi. org/10.1080/13594320801969707

Nielsen, M. B., Matthiesen, S. B., Einarsen, S. (2010). The impact of methodological moderators on prevalence rates of workplace bullying. A meta-analysis. Journal of Occupational and Organizational Psychology, 83(4), 955-979. pp. 955-979. Accessed at: $h t t p: / / d x . d o i$. org/10.1348/096317909X481256. (8/9/2016)

Nielsen, M.B., Notelaers, G., Einarsen, S. (2011). Measuring exposure to workplace bullying. In:

Einarsen S., Hoel H., Zapf D., Cooper C.L., (Eds.). Bullying and Harassment in the workplace: Developments in Theory, Research, and Practice. CRC Press, pp 107-128.

Quine, L. (1999). Workplace bullying in NHS community trust: Staff questionnaire survey. Br. Med. J., 318 (7178), 228-232. doi.org/10.1136/bmj.318.7178.228

Salin, D. (2001). Prevalence and forms of bullying among business professionals: A comparison of two different strategies for measuring bullying. European Journal of Work and Organizational Psychology, 10(4), 425-441. doi: 10.1080/13594320143000771.

Salin, D. (2003). Bullying and Organizational Politics in competitive and rapidly changing work environments. International Journal of Management and Decision Making, 4, (1), 35-46. doi.org/10.1504/IJMDM.2003.002487

Salin, D. (2015). Risk factors of workplace bullying for men and women: The role of the psychosocial and physical work environment. Scandinavian Journal of Psychology, 56(1), 69-77. doi: 10.1111/sjop.12169

Silva, I. V., Aquino, E. M.L., Pinto, I. C. M. (2017). Psychometric properties of the Negative Acts Questionnaire for the detection of workplace bullying: an evaluation of the instrument with a sample of state health care workers. Revista Brasileira de Saúde Ocupacional, 42, ISSN: 2317-6369 doi.org/10.1590/2317-6369000128715

Tsuno T., Kawakami, N., Inoue, A., Abe, K. (2010). Measuring workplace bullying: reliability and validity of the Japanese version of the Negative Acts Questionnaire. Journal of Occupational Health, 52(4), 216-226. doi: 10.1539/joh.L10036

Vallerand, R.J. (1989). Vers une méthodologie de validation trans-culturelle de questionnaires psychologiques: Implications pour la recherche en langue française [Towards a methodology of trans-cultural validation of psychological questionnaire: Implications for research in the French language]. Psychologie Canadienne, 30, 662-680.

Vukelić, M., Čizmić, S., Petrović, I.B., Tenjović, L., Giorgi, G. (2015). Psychometric properties of the Serbian version of the Negative Acts Questionnaire - Revised. Psihologija 48(1), 19-33. doi: 10.2298/PSI1501019V

Zapf, D., Knorz, C., Kulla, M. (1996). On the relationship between mobbing factors, and job content, social work environment, and health outcomes. European Journal of Work and Organizational Psychology, 5(2), 215-237. doi.org/10.1080/13594329608414856

Zapf, D., Einarsen, S.(2001). Bullying in the workplace: recent trends in research and practice - an introduction. European Journal of Work and Organizational Psychology, 10(4), 369-373. doi.org/10.1080/13594320143000807 
Željka Radošević, Dolores Britvić, Boris Tot: Factor structure and descriptive characteristics of the...

Zapf, D., Gross, C. (2001). Conflict escalation and coping with workplace bullying: A replication and extension. European Journal of Work and Organizational Psychology, 10, 497-522. https://doi.org/10.1080/13594320143000834

Zapf, D., Escartin, J., Einarsen, S., Hoel, H., Vartia, M. (2011). Empirical Findings on Prevalence and Risk Groups of Bullying in the Workplace. In Einarsen, S., Hoel, H., Zapf, D., Cooper, C.L. (Eds.), Bullying and Harassment in the Workplace. Developments in Theory, Research, and Practice. (2nd ed., pp. 75-105). Boca Raton, FL: CRC Press.

\section{Appendix 1 The Croatian version of the Negative Acts Questionnaire - Revised (NAQ-R)}

Uz svaku tvrdnju molimo zaokružite broj koji odgovara Vaš em iskustvu koliko često ste doživjeli opisano negativno ponašanje na radnom mjestu u posljednjih dvanaest mjeseci.

1

3

4

5

\begin{tabular}{|c|c|c|c|c|}
\hline Nikad & $\begin{array}{c}\text { Vrlo rijetko } \\
\text { (nekoliko puta tijekom } \\
\text { godine) }\end{array}$ & $\begin{array}{l}\text { Ponekad } \\
\text { (najmanje jednom } \\
\text { godišnje) }\end{array}$ & $\begin{array}{c}\text { Često } \\
\text { (njmanje jednom tjedno) }\end{array}$ & $\begin{array}{c}\text { Vrlo često } \\
\text { (gotovo svaki dan) }\end{array}$ \\
\hline
\end{tabular}

\begin{tabular}{|l|l|l|l|l|l|}
\hline 1. Uskraćuju Vam se informacije od važnosti za posao koji radite. & 1 & 2 & 3 & 4 & 5 \\
\hline 2. Poniženi ste i ismijavani u vezi obavljanja poslova. & 1 & 2 & 3 & 4 & 5 \\
\hline 3. Daju Vam se poslovi ispod razine Vaše stručnosti. & 1 & 2 & 3 & 4 & 5 \\
\hline 4. Dobivate beznačajne, trivijalne ili neugodne zadaće, a ključni poslovi Vam se oduzimaju. & 1 & 2 & 3 & 4 & 5 \\
\hline 5. Šire se tračevi i glasine o Vama. & 1 & 2 & 3 & 4 & 5 \\
\hline 6. Ignorirani ste, isključeni i izolirani iz zbivanja. & 1 & 2 & 3 & 4 & 5 \\
\hline 7. Doživjeli ste uvredljive primjedbe ili napade na Vas, Vaše stavove ili Vaš privatni život. & 1 & 2 & 3 & 4 & 5 \\
\hline 8. Viče se na Vas ili ste meta nečijeg bijesa, spontane ljutnje. & 1 & 2 & 3 & 4 & 5 \\
\hline 9. Zastrašuje Vas se s uperenim prstom u Vas, ulazi se u Vaš osobni prostor, naguravanje, blokiranje. & 1 & 2 & 3 & 4 & 5 \\
\hline $\begin{array}{l}\text { 10. Upućeni su Vam savjeti ili poruke preko drugih da biste trebali prestati raditi svoj posao, potražiti } \\
\text { drugi ili dati otkaz. }\end{array}$ & 1 & 2 & 3 & 4 & 5 \\
\hline 11. Ponavljano se ističe ili traži Vaša pogreška/e. & 1 & 2 & 3 & 4 & 5 \\
\hline 12. Ignorira se Vaš dolazak ili neprijateljski se reagira kada se pojavite ili kada se obraćate. & 1 & 2 & 3 & 4 & 5 \\
\hline 13. Stalno i uporno se kritizira Vaš rad. & 1 & 2 & 3 & 4 & 5 \\
\hline 14. Ignoriraju se Vaše mogućnosti i zanemaruje Vaše mišljenje. & 1 & 2 & 3 & 4 & 5 \\
\hline 15. Šale se na Vaš račun. & 1 & 2 & 3 & 4 & 5 \\
\hline 16. Dobivate zadatke sa nerazumnim ili nemogućim ciljevima i rokovima. & 1 & 2 & 3 & 4 & 5 \\
\hline 17. Iznose se neprovjerene tvrdnje i optužbe protiv Vas. & 1 & 2 & 3 & 4 & 5 \\
\hline 18. Pretjerano se kontrolira ili prati kako obavljate svoj posao. & 1 & 2 & 3 & 4 & 5 \\
\hline 19. Vrši se pritisak da ne tražite ili ne koristite pripadajuća prava (naknada za prekovremeni, putni \\
trošak, godišnji, bolovanje i sl.). & 1 & 2 & 3 & 4 & 5 \\
\hline 20. Izloženi ste prekomjernom zadirkivanju i sarkazmu. & 1 & 2 & 3 & 4 & 5 \\
\hline 21. Izloženi ste obimnom poslu koji ne možete obaviti. & 1 & 2 & 3 & 4 & 5 \\
\hline 22. Prijeti Vam se nasiljem, fizičkim zlostavljanjem ili ste zaista doživjeli fizičko zlostavljanje. & 1 & 2 & 3 & 4 & 5 \\
\hline
\end{tabular}

Slijedi pitanje koje se odnosi na Vašu osobnu procjenu izloženosti zlostavljanju na radnom mjestu (mobingu).

Zlostavljanje na radnom mjestu (mobing) definira se kao situacija/e u kojima je jedna ili više osoba duže vrijeme izložena i doživljava negativna, uznemirujuća ponašanja na radnom mjestu od strane jedne ili više osoba i pri tome se osjeća metom napada tim ponašanjima i nije u mogućnosti ili ima poteškoće da se obrani. Jedan, izolirani incident nije zlostavljanje. 
Koristeći gornju definiciju molimo odgovorite (zaokruživanjem odgovora koji najbolje opisuje Vaše iskustvo) jeste li bili zlostavljani na radnom mjestu u posljednjih 12 mjeseci?

a) $\mathrm{Ne}$

b) Da, vrlo rijetko

c) Da, nekoliko puta mjesečno

d) Da, nekoliko puta tjedno

e) Da, svakodnevno

\section{Appendix 2: Original NAQ-R - Negative Acts Questionnaire-Revised (C) Einarsen, Hoel \& Notelaers, 2009}

The following behaviours are often seen as examples of negative behaviour in the workplace. Over the last six months, how often have you been subjected to the following negative acts at work?

Please circle the number that best corresponds with your experience over the last six months:

\begin{tabular}{|c|c|c|c|c|}
\hline 1 & 2 & 3 & 4 & 5 \\
\hline Never & Now and then & Monthly & Weekly & Daily \\
\hline
\end{tabular}

\begin{tabular}{|c|c|c|c|c|c|}
\hline 1. Someone withholding information which affects your performance & 1 & 2 & 3 & 4 & 5 \\
\hline 2. Being humiliated or ridiculed in connection with your work & 1 & 2 & 3 & 4 & 5 \\
\hline 3. Being ordered to do work below your level of competence & 1 & 2 & 3 & 4 & 5 \\
\hline 4. Having key areas of responsibility removed or replaced with more trivial or unpleasant tasks & 1 & 2 & 3 & 4 & 5 \\
\hline 5. Spreading of gossip and rumours about you & 1 & 2 & 3 & 4 & 5 \\
\hline 6. Being ignored or excluded (being 'sent to Coventry') & 1 & 2 & 3 & 4 & 5 \\
\hline $\begin{array}{l}\text { 7. Having insulting or offensive remarks made about your person (i.e. habits and background), your } \\
\text { attitudes or your private life }\end{array}$ & 1 & 2 & 3 & 4 & 5 \\
\hline 8. Being shouted at or being the target of spontaneous anger (or rage) & 1 & 2 & 3 & 4 & 5 \\
\hline $\begin{array}{l}\text { 9. Intimidating behaviour such as finger-pointing, invasion of personal space, shoving, blocking/barring } \\
\text { the way }\end{array}$ & 1 & 2 & 3 & 4 & 5 \\
\hline 10. Hints or signals from others that you should quit your job & 1 & 2 & 3 & 4 & 5 \\
\hline 11. Repeated reminders of your errors or mistakes & 1 & 2 & 3 & 4 & 5 \\
\hline 12. Being ignored or facing a hostile reaction when you approach & 1 & 2 & 3 & 4 & 5 \\
\hline 13. Persistent criticism of your work and effort & 1 & 2 & 3 & 4 & 5 \\
\hline 14. Having your opinions and views ignored & 1 & 2 & 3 & 4 & 5 \\
\hline 15. Practical jokes carried out by people you don't get on with & 1 & 2 & 3 & 4 & 5 \\
\hline 16. Being given tasks with unreasonable or impossible targets or deadlines & 1 & 2 & 3 & 4 & 5 \\
\hline 17. Having allegations made against you & 1 & 2 & 3 & 4 & 5 \\
\hline 18. Excessive monitoring of your work & 1 & 2 & 3 & 4 & 5 \\
\hline $\begin{array}{l}\text { 19. Pressure not to claim something which by right you are entitled to (e.g. sick leave, holiday } \\
\text { entitlement, travel expenses) }\end{array}$ & 1 & 2 & 3 & 4 & 5 \\
\hline 20. Being the subject of excessive teasing and sarcasm & 1 & 2 & 3 & 4 & 5 \\
\hline 21. Being exposed to an unmanageable workload & 1 & 2 & 3 & 4 & 5 \\
\hline 22. Threats of violence or physical abuse or actual abuse & 1 & 2 & 3 & 4 & 5 \\
\hline
\end{tabular}

Have you been bullied at work? We define bullying as a situation where one or several individuals persistently over a period of time perceive themselves to be on the receiving end of negative 
Željka Radošević, Dolores Britvić, Boris Tot: Factor structure and descriptive characteristics of the...

acts from one or several persons, in a situation where the target of bullying has difficulty in defending him or herself against these acts. We will not refer to a one-off incident as bullying.

Using the above definition, please state whether you have been bullied at work over the last six months?
a) No (continue at question ?)
b) Yes, but only rarely
c) Yes, now and then
d) Yes several times per week
e) Yes, almost daily

\section{(®) $\Theta \Theta$}

Međunarodna licenca / International License:

Creative Commons Attribution-NonCommercial-NoDerivatives 4.0. 